\title{
ОСНОВНІ ОСОБЛИВОСТІ АНАЛІЗУ ЕКСПЛІЦИТНИХ ОБРАЗІВ СТИХІЙ ПРИРОДИ НА УРОКАХ УКРАЇНСЬКОЇ ЛІТЕРАТУРИ В 10-11 КЛАСАХ
}

Орищенко І. М., аспірант кафедри мовно-літературної освіти та культури мови, Україна, м. Ніжин, Ніжинський державний університет імені Миколи Гоголя DOI: https://doi.org/10.31435/rsglobal_conf/25112020/7251

\begin{abstract}
Modern Methodology of teaching Ukrainian literature faces with the problem of finding effective approaches that could provide high-quality knowledge for modern students and arouse their interest in Ukrainian literature as a scientific discipline. This goal can be achieved through the introduction of new methodologies that will help to look at the work of art from a different perspective and reveal its hidden areas. This article examines the method of processing explicit images of natural elements on the basis of chronotopic analysis during the lessons of Ukrainian literature in the senior classes of secondary schools. The research topic includes the study of forms of representation of images of water, fire, air and earth at different structural levels of the work, identifying their function, meaning and development of step-by-step methods of their processing. It also offers samples of practical exercises created on the basis of processing images of natural elements.
\end{abstract}

Keywords: an approach, the explicit images, the images of the natural elements, a chronotope, the chronotopic analysis.

Вступ. Українська література включає в себе ряд художніх творів з яскравою стихійною образністю, які потребують чіткої послідовності кроків для їх опрацювання. Однак, сучасна методична наука не виробила єдиного підходу до їх опрацювання. Здебільшого вони розглядають в контексті позасюжетних елементів та не виокремлюють в окрему самостійну групу. Хоч вони насправді можуть стати потужним джерелом для аналізу художнього твору та розкриття його додаткових та прихованих сенсів, оскільки у них закодоване концептуальне ядро авторської світоглядної моделі.

Мета статті - запропонувати методику опрацювання експліцитних образів стихій природи на уроках української літератури в 10-11 класах загальноосвітніх шкіл.

Методи досліджень. Наукове дослідження опирається на емпіричні методи дослідження (спостереження), загальнонаукові методи дослідження (аналіз, синтез, індукція та дедукція, узагальнення і т.д.) та літературознавчі (міфологічний, психоаналітичний (Г. Юнг, Г. Башляр, Н. Фрай)).

Результати дослідження. Методика вивчення образів природних стихій $\epsilon$ двоскладною, тобто вона включає в себе опрацювання образів природних стихій, виражених експліцитно, а також цих же образів, виражених імпліцитно (архетипний рівень, зображення інших художніх елементів).

Експліцитні образи природних стихій реалізуються через позасюжетні елементи, тому вони $є$ візуально видимими та доступними для сприймання учнів. На відміну від них, імпліцитні образи води, вогню, повітря та землі не мають свого чіткого формального вираження. У старшокласників виникають певні труднощі в процесі їх пошуку та аналізу.

У контексті художніх творів розрізняють три групи образів природних першоелементів, які репрезентують себе у формі:

- «архетипних концептів» [3, с. 36] (образ землі та лісу у повісті «Земля» О. Кобилянської, гори, ватра, Черемош у повісті «Тіні забутих предків» М. Коцюбинського.

- персоніфікованих, міфологічних одиниць (нявка, чунайстир, щезник з повісті «Тіні забутих предків» М. Коцюбинського, Мавка, Водяник, Перелесник, Потерчата, Лісовик в драмі-феєрії «Лісова пісня» Лесі Українки);

- національних концептів, які відображають менталітет української народу (земля у повісті «Кайдашева сім`я» Івана Нечуя-Левицького та романі «Хіба ревуть воли, як ясла повні?» Панаса Мирного та Івана Рудченка).

Експліцитні образи стихій природи зазвичай представлені у творах через рівень позасюжетних елементів: 
- Вони найчастіше реалізуються в контексті пейзажів (опис Черемоша, ватри та гір у повісті М. Коцюбинського «Тіні забутих предків»; річки Десни та городу у кіноповісті О. Довженка «Зачарована Десна»; образ горба із новели В. Стефаника «Камінний хрест», міфологічні образи Русалки, Водяника (вода), Перелесника (вогонь+повітря), Потерчат (вогонь+вода), лісу (земля) та озера у драмі-феєрії Лесі Українки «Лісова пісня»). Образи природних стихій несуть у собі важливе контекстуальне навантаження, яке було згенероване свідомістю письменника та позначене впливом його світоглядних уявлень, а також окреслюють художні час та простір, за яких відбуваються події у творі.

- Експліцитні образи природних першоелементів відображаються у назвах творів через їх заголовки (повість «Земля» О. Кобилянської, новела «Камінний хрест» В. Стефаника, драма-феєрія «Лісова пісня» Лесі Українки, збірка «Сонячні кларнети» П. Тичини, кіноповість «Зачарована Десна» О. Довженка, «Україна у вогні» О. Довженка) і викликають алюзії та конкретизують просторово-часові ознаки літературного твору.

- Авторські відступи та внутрішні монологи персонажів (роздуми автора про річку Десну у кіноповісті «Зачарована Десна» О. Довженка, міркування письменника про сонце (стихія вогню), Кононівські поля (земля) у новелі з ознаками «поезії в прозі» «Intermezzo» М. Коцюбинського) допомагають повніше осягнути постать письменника та запропоновану ним світоглядну парадигму.

- Художні деталі («Сіра маленька пташка, як грудка землі, низько висіла над полем» (новела «Intermezzo» М. Коцюбинського); «Здавалося, що ті очі важили би так, як олово, а решта тіла, якби не очі, то полетіла би з вітром, як пір'я» (новела «Новина» В. Стефаника); «Пахнув він [дід] теплою землею і трохи млином» (кіноповість «Зачарована Десна» О. Довженка), які найчастіше реалізуються через порівняння, епітети чи символи, допомагають увиразнити архетипну образність твору в межах певного хронотопу.

- Уставні епізоди (розповідь Миколи про утворення землі та ватри арідником у повісті «Тіні забутих предків» М. Коцюбинського; висловлювання автора про Десну у кіноповісті «Зачарована Десна» О. Довженка) сприяють усвідомленню концептуального задуму письменника.

Архетипні першообрази стихій природних елементів використовуються для:

- розгортання сюжету та розбудови його композиції: вплив природних стихій на поведінку, дії та вчинки персонажів повісті «Тіні забутих предків» М. Коцюбинського (річка Черемош забирає життя Марічки, що спровокувало кардинальну зміну в долі Івана та сприяло трагічній розв'язці: смерть чоловіка від рук нявки, яка постала в образі його коханої); згадка дорослого письменника про річку Десну у кіноповісті «Зачарована Десна» О. Довженка; топос моря у автобіографічному романі «Майстер корабля» Ю. Яновського, який зосереджує навколо себе усі події у творі;

- поглиблення конфлікту та створення напруженості становища: чвари за землю у повісті «Кайдашева сім`я» Івана Нечуя-Левицького; позбавлення своєї землі у Чіпки Варениченка із роману «Хіба ревуть воли, як ясла повні?» Панаса Мирного та Івана Білика, що породило «пропащу силу»; образ горба з новели «Камінний хрест» В. Стефаника як символ рідної землі, який допомагає розкрити трагізм еміграційної тематики; мороз і голод у повісті «Поза межами болю» О. Турянського штовхають персонажів твору на нелюдські вчинки;

- формування різних сюжетно-композиційних стадій: смерть Марічки у водах Черемоша 3 повісті «Тіні забутих предків» М. Коцюбинського є кульмінацією; пробудження лісових мешканців на озері в драмі-феєрії «Лісова пісня» створює експозицію.

Першорядного значення набувають експліцитні образи води, вогню, повітря та землі для становлення доль образів персонажів:

- вони групують навколо себе персонажів твору: вода (Водяник, Русалка Лісова, «Той, що греблі рве»), земля (Лісовик, Русалка Польова, «Той, що в скалі сидить»), вогонь (Перелесник, Потерчата), повітря (Перелесник, Пропасниця) у драмі-феєрії «Лісова пісня» Лесі Українки;

- поєднуються 3 персонажами твору підсвідомим зв'язком, утворюючи тандем: вода Марічка, мольфар Юра - повітря, Палагна - земля, Іван - вогонь у повісті «Тіні забутих предків» М. Коцюбинського;

- $\epsilon$ рушійною силою, яка спонукає головних персонажів до дій: саме бажання оволодіти землею підштовхує Саву до братовбивства (повість «Земля» О. Кобилянської); 
гармонія та збалансованість світових стихій у природі дарують душевний спокій та сили для боротьби головному герою «Intermezzo» М. Коцюбинського; стихійна комбінація, представлена у формі сполуки повітря, води та холоду штовхають персонажів повісті-поеми «Поза межами болю» О. Турянського на гріховний вчинок: канібалізм;

- репрезентують узагальнені світоглядні домінанти та символічні значення: земля $\epsilon$ джерелом плодючості та життя (тісний зв'язок матері Сашка із землею у кіноповісті «Зачарована Десна» О. Довженка), уособлює зв'язок поколінь та предків (образ дуба у драміфеєрії «Лісова пісня» Лесі Українки є символом Дерева життя, яке пов'язує три світи у єдине ціле: реальний, потойбічний та ідеальний), є останнім притулком (домовиною) для Михайла 3 повісті «Земля» О. Кобилянської; вода символізує плинність життя та його змінність (саме на березі річки Десна спливло за водою дитинство письменника з кіноповісті «Зачарована Десна» О. Довженка), вона також втілює скороминущість сущого (річка Черемош забирає життя Марічки 3 повісті «Тіні забутих предків» М. Коцюбинського); вогонь репрезентує переродження (трансформація психологічного та фізичного стану Мавки під впливом вогню у драмі-феєрії «Лісова пісня» Лесі Українки) та наділяється чудодійними властивостями (ватра $є$ магічним символом для гуцулів, де вони знаходять захист та затишок у повісті «Тіні забутих предків» М. Коцюбинського); повітря уособлює руйнування та страждання (буря, яку зупинив мольфар Юра у повісті «Тіні забутих предків» М. Коцюбинського та снігова буря в Албанських горах у повісті-поемі «Поза межами болю» О. Турянського).

Образи стихій води, вогню, повітря та землі позначені впливом жсанрових характеристик твору: вони набувають відмінних рис для творів різних епічних жанрів: великих (роман), середніх (повість) та малих (новела, оповідання, нарис). У великих та середніх жанрах вони реалізуються через поза сюжетні елементи твору (пейзажі: описи гір та річки Черемош у повісті «Тіні забутих предків» М. Коцюбинського) та через персоніфіковані образи, які постають самостійними дійовими персонажами твору (Перелесник, Русалка, Водяник, Лісовик в драмі-феєрії «Лісова пісня» Лесі Українки; Нявка, Чугайстир, Щезник в повісті «Тіні забутих предків» М. Коцюбинського); у малих епічних жанрах образи природних стихій репрезентовані через деталь (образ камінного хреста 3 однойменної новели В.Стефаника, важкого каменя та вогненного пасу 3 новели «Новина» В. Стефаника). Вплив образів води, вогню, повітря та землі сприяв утворенню нових жанрових форм та їх взаємопроникненню: психологічна новела «Intermezzo» М. Коцюбинського виникла в результаті зосередженості письменника на процесі сприйняття ліричним персонажем природи (сонця, поля, неба) та породжених нею переживань та почуттів; новела «Момент» В. Винниченка поєднує у собі реалістичне змалювання дійсності та філософський підтекст, який розкривається 3 допомогою образів природних стихій; залучення образів води, вогню, повітря та землі та фантастичного сюжету створюють жанр драми-феєрії «Лісова пісня» Лесі Українки; залучення образи водної стихії допомогло створити новаторський твір - автобіографічний роман «Майстер корабля» Ю. Яновського, для якого характерна умовність часових та просторових характеристик; поема в прозі «Поза межами болю» О. Турянського та кіноповість «Зачарована Десна» О. Довженка, виникли в результаті згадок митців про своє минуле.

Особливості застосування компонентів з образними стихійними утвореннями допомагають розкрити стильові характеристики епічного твору: модерна література використовує образи води, вогню, повітря та води для представлення внутрішнього світу особистості, iї емоцій, переживань та виявлення психологічних зв’язків, які поєднують людську душу з природою: навколишня дійсність $€$ джерело натхнення та життєвої енергії (психологічна новела «Intermezzo» М. Коцюбинського, новела «Момент». В. Винниченка), крім того вона тяжіє до залучення несвідомих виявів та чинників, які намагається пояснити 3 допомогою образів природних стихій (новела «Новина» В. Стефаника). У творах модерної літератури використовуються язичницьких образів та символів, які репрезентуються через образи природних першоелементів та відображають національні та загальнокультурні концепти (драма-феєрія «Лісова пісня» Лесі Українки, повість «Тіні забутих предків» М. Коцюбинського). Так, неоромантична література прагнула проникнути у трансцендентний світ та пізнати механізм внутрішніх душевних переживань особистості 3 допомогою архетипної образності, язичницьких символів та міфологізму (повість «Земля» О. Кобилянської, драма-феєрія «Лісова пісня» Лесі Українки). Образи води, вогню, повітря та землі персоніфікуються та стають самостійними дійовими особами, що провокує певні інновації в оповідній формі та часопросторових характеристиках твору (умовність зображення, розмитість 
часових та просторових рамок, надчасовість та позапросторовість дій) (поема в прозі «Поза межами болю» О. Турянського, кіноповсть «Зачарована Десна» О. Довженка та автобіографічний роман «Майстер корабля» Ю. Яновського).

До експліцитних образів стихій природних першоелементів слід застосовувати хронотопний шлях аналізу, оскільки вони існують у площинах простору та часу, завдяки чому перебувають у тісних зв'язках із різними текстовими рівнями: сюжетом, образамиперсонажами, підтекстом. Основне завдання хронотопного аналізу - вивчити образи природних першоелементів крізь часо-просторові характеристики літературного тексту, з'ясувати їх роль у розбудові авторської картини світу. Під час застосування хронотопного аналізу учні оцінюють часо-простір твору, вчаться досліджувати різноманітні способи реалізації образів стихій природи в контексті хронотопу, інтерпретувати системні зв'язки, які існують між зазначеними образами та часо-просторовою організацією мистецького тексту.

Методика опрацювання образів природних стихій була розроблена та впроваджена 3 урахуванням напрацювань Ю. Бондаренка [1, с. $71-88]$ :

1. Виокремлення наявних у творі хронотопів;

2. Опрацювання образів води, вогню, повітря та землі в межах окремого хронотопу;

3. Установлення зв'язків між різними хронотопами з допомогою образів природних стихій.

Першим етапом у процесі опрацювання образів води, вогню, повітря та землі на основі хронотопного аналізу $є$ пошук та визначення усіх хронотопів, які існують у просторі літературного тексту. 3'ясування зв'язків між образи природних стихій та хронотопом допомагає старшокласникам цілісно осягнути усю мистецьку картину, репрезентовану у творі. Спочатку учитель повинен познайомити учнів з суттю теоретичного поняття «хронотоп» та основними його елементами. Стратегія дослідження образів води, вогню, повітря та землі у часі та просторі мистецького твору залежить від композиційних особливостей художнього тексту:

- встановлювати характер взаємозв'язків між часо-простором та образами стихій природи простіше у творах із хронологічною формою побудови сюжету, адже в ній події вибудовуються послідовно;

- у творах із ретроспективною композицією образи води, вогню, повітря та землі формують простір художнього твору, конкретизують його проблематику та основний конфлікт.

Старшокласники мають засвоїти, що хронотоп становить собою завершену часопросторову картину мистецького твору. У першу чергу учителю слід навчити учнів визначати часові та просторові рамки тексту, знаходити образи стихій води, вогню, повітря та землі у них, визначати їх місце та функціональне навантаження. Досягти цього можливо 3 допомогою правильно організованого етапу формування знань, умінь та навичок. Ця стадія визначає набуття учнями теоретичних відомостей про часо-простір мистецького твору та зв'язків, які існують між ними та образами води, вогню, повітря та землі. Старшокласники повинні бути поінформованими про те, що:

- події у творі окреслюються певними часовими та просторовими рамками, а образи стихій природи поглиблюють, уточнюють та конкретизують місце подій;

- образи води, вогню, повітря та землі відображають пов'язаність проблематики 3 певним часо-просторовим періодом, описаним у творі;

- під образами персонажами слід розуміти одне покоління людей, які відображають світогляд певної історичної доби, а образи природних першоелементів впливають на їх поведінку і цим самим рухають сюжет;

- наявність у тексті мовних конструкцій із образами води, вогню, повітря та землі, які відображають атмосферу, зображеного у творі часу.

Досягти цього можливо за рахунок застосування таких видів діяльності на уроках української літератури у 10 - 11 класах: опрацювання літературно-критичних статей про особливості організації часо-простору у художньому творі, розгляд та опрацювання схем, таблиць, конспектування розповіді учителя, створення презентацій про взаємозв'язок образів води, вогню, повітря та землі 3 художнім хронотопом твору, ведення термінологічних словників, складання порівняльних таблиць та опорних схем.

На наступному етапі старшокласники разом 3 учителем опрацьовують сюжетнозмістовий рівень твору, визначаючи часо-просторові рамки твору, встановлюючи кількість 
хронотопів та їх класифікацію, роздрібнюючи їх на мікрохронотопи, визначаючи місце образів чотирьох природних стихій у межах кожного окремого хронотопу.

Робота в межах окремого хронотопу становить собою процес дослідження чинників упливу образів природних першоелементів на часо-просторові особливості твору та продукування менших за розміром хронотопів 3 допомогою виявлення їх позиції у загальній часо-просторовій побудові літературного тексту.

Заради кращого розкриття істотності впливу образів води, вогню, повітря та землі на часо-просторову організацію твору доцільно застосовувати такі методи, прийоми та засоби організації навчальної діяльності учнів на уроках української літератури:

- евристична бесіда за заздалегідь складеними запитаннями допоможе учням усвідомити спрямованість художнього потенціалу образів природних стихій на організацію хронотопних властивостей мистецького твору:

1. Визначте часові та просторові рамки зображених у творі подій. Яких характеристик та особливостей вони набувають?

2. Які образи природних стихій (води, вогню, повітря, землі) наявні в тексті? Опишіть, яким чином вони зображені в часі й просторі літературного твору.

3. Чи можете ви виокремити дрібніші хронотопи в загальному сюжетному часо-просторі художнього тексту? Як вони взаємодіють між собою?

- розв’язання проблемних ситуацій та виконання творчих завдань: Чи мають вплив образи води, вогню, повітря та землі на організацію часу та простору у повісті «Тіні забутих предків» М. Коцюбинського? Підтвердити свої слова цитатами з твору.

- виконання самостійної роботи учнів, основне завдання якої полягає у структуруванні образів природних елементів у відповідності до окремого хронотопу та загальної часопросторової побудови художнього тексту;

- складання порівняльних таблиць чи структурно-логічних схем.

Висновки. Отже, методика опрацювання експліцитних образів природних стихій на основі хронотопного аналізу створить широкий простір для розвитку аналітичних навичок учнів та сформує альтернативні способи дослідження літературного тексту, тобто в старшокласників 3'явиться можливість вибору того чи іншого маршруту для пізнання внутрішнього простору твору та дослідження індивідуального стилю письменника. Проблема опрацювання образів води, вогню, повітря та землі може бути розв'язаною шляхом застосування комплексного підходу, а саме: їх дослідження в більшості художніх рівнів тексту, а також з допомогою застосування різноманітних підходів, принципів та шляхів аналізів.

\section{ЛIТЕРАТУРА}

1. Бондаренко Ю. Методика шкільного вивчення сюжетно-композиційної організації епічного твору: теорія і практика / Ю. Бондаренко. - Ніжин : НДУ ім. М. Гоголя, 2012. - 143 с.

2. Ісаєва О.О. Теорія і технологія розвитку читацької діяльності старшокласників у процесі вивчення зарубіжної літератури: монографія/ О. О. Ісаєва. - К.: Вид-тво НПУ імені М. П. Драгоманова, 2003. - 380 с.

3. Лабенська $Є$. Типологія образності природних стихій у сучасному англомовному поетичному дискурсі / С. О. Лабенська // Науковий вісник ХДУ. Серія Германістика та міжкультурна комунікація. - 2019. - №2. - С. 34 - 42.

4. Пасічник Е. А. Методика викладання української літератури в середніх навчальних закладах: Навчальний посібник для студентів вищих закладів освіти / Е. А. Пасічник. - К.: Ленвіт, 2000. - 384 с.

5. Усатий, А. В. Формування читацьких умінь учнів старших класів у процесі вивчення літературних творів: монографія / А. В. Усатий. - Житомир: Вид-во ЖДУ ім. І. Франка, 2012. - 172 с. 